\title{
Koleksi dan Identifikasi Bakteri Penambat N Pada Pusat Lokasi Tanaman Kedelai Edamame (Glycine max (L.) Merr.) Di Kabupaten Jember
}

\author{
Author(s): Vivin Nur'Aini Fajrin*(1); Iqbal Erdiansyah ${ }^{(1)}{ }^{\text {; Damanhuri(1) }}$ \\ (1) PS. Teknologi Produksi Tanaman Pangan, Jurusan Produksi Pertanian, Politeknik Negeri Jember \\ * Corresponding author: vivinnuraini13061995@gmail.com
}

\begin{abstract}
ABSTRAK
Penelitian ini bertujuan untuk mengetahui dan mengidentifikasi bakteri penambat $\mathrm{N}$ pada pusat lokasi tanaman kedelai edamame (Glycine max (L.) Merr.) di Kabupaten Jember. Penelitian ini dilakukan dari bulan September 2016 hingga November 2016. Kegiatan penelitian dilakukan di Laboratorium Biosains Politeknik Negeri Jember. Penelitian ini terdiri dari 2 faktor dengan 6 perlakuan dan 3 ulangan, yaitu faktor Lokasi (L) yang terdiri dari lokasi pengambilan tanah di Kecamatan Jenggawah (L1) dan di Kecamatan Ajung (L2), faktor Kedalaman (K) terdapat 3 taraf yaitu kedalaman pengambilan tanah $5 \mathrm{~cm}$ dari permukaan tanah (K1), $10 \mathrm{~cm}$ dari permukaan tanah $(\mathrm{K} 2)$, dan $15 \mathrm{~cm}$ dari permukaan tanah (K3). Data dianalisis secara kuantitatif dan kualitatif, data kuantitatif dilakukan dengan cara menghitung jumlah koloni bakteri menggunakan metode TPC (Total Plate Count), data kualitatif didapatkan dari pengamatan gram staining, pengamatan kecepatan pertumbuhan bakteri dan pengamatan kemurnian bakteri. Hasil penelitian ini menunjukan bahwa bakteri yang diisolasi dapat dikoleksi dan diidentifikasi sebagai jenis bakteri penambat $\mathrm{N}$ tipe bakteri Rhizobium spp. yang ditunjukkan dengan warna putih bening dan merah muda setelah dibiakkan dalam media seleksi YEMA + Congo Red. Bakteri Rhizobium sp. yang memiliki tingkat adaptasi tertinggi berasal dari Kecamatan Ajung pada kedalaman $15 \mathrm{~cm}$ dari permukaan tanah, yaitu sebesar $6,88 \times 1030 \mathrm{CFU} / \mathrm{g}$ tanah.
\end{abstract}

\section{Kata Kunci:}

Bakteri penambat $\mathrm{N}$;

Kedelai edamame;

Kabupaten Jamber;
$N$ fixing

bacteria;

Edamame soybean;

Jember district;
Keywords: $\quad$ This research purposed to known fixing bacteria at edamame soybean's field Center in

\section{ABSTRACT}

Jember Regency. This research was conducted along 3 months from September 2016 until November 2016. The depth of a land activity had done in Jember subdistrict and the testing of $N$ Fixing Bacteria that had done in Biosains Laboratory from State Polytechnic of Jember. There were 2 factors with 6 treatments and 3 replications. The first factor was location factor (L) consisted of located in Jenggawah subdistrict (L1) and in Ajung subdistrict (L2) and the second factor was 3 levels of the depth land ( $k$ ) consisted of $5 \mathrm{~cm}$ the depth of a land from a land surface (K1), $10 \mathrm{~cm}$ from a land surface (K2), $15 \mathrm{~cm}$ from a land surface (K3). The data of this research analyzed as quantitative and qualitative. The quantitative data collected by counting the colony by TPC method (Total Plate Count) and the qualitative data had gotten from observation of gram staining, observation of the speed of growing bacteria and observation of a pure bacteria. The result of this research showed that bacteria which had isolated from vegetable soybean (Glycine max (L.) Merr.) was Rhizobium spp, it is bacteria type of $N$ fixing bacteria, the result showed from observation of a pure bacteria was a pure white and pink after bred in Yema selection media+congo red.Rhizobium sp. which has the highest adaptation level is from Ajung District.It was taken at $15 \mathrm{~cm}$ below the ground surface. The adaptation levels 6,88x1030 CFU/gram of soil was a pure white and pink after bred in Yema selection media+congo red. 


\section{PENDAHULUAN}

Kedelai (Glycine $\max$ (L.) Merr.) merupakan salah satu komoditi pangan kaya protein yang banyak digunakan dalam kehidupan sehari-hari. Kedelai merupakan salah satu jenis tanaman palawija yang banyak dimanfaatkan oleh masyarakat Indonesia baik dalam industri pangan maupun dalam industri pakan (Badan Penelitian dan Pengembangan Pertanian, 2014).

Kedelai yang saat ini banyak diminati oleh masyarakat Indonesia adalah jenis tanaman kedelai edamame. Kabupaten Jember merupakan salah satu sentra pengembangan tanaman kedelai edamame yang hasilnya diekspor ke Jepang. Potensi dan prospek budidaya tanaman kedelai edamame di Kabupaten Jember sangat tinggi sehingga menjadikan Kabupaten Jember sebagai pusat pengembangan budidaya kedelai edamame secara nasional, hal ini dikarenakan Kabupaten Jember terletak pada ketinggian 0-3.300 meter diatas permukaan laut (dpl), sebagian besar wilayahnya terletak pada ketinggian antara 100 hingga 500 meter dpl yang memiliki luasan lahan $800 \mathrm{Ha}$ untuk budidaya edamame dengan produktivitas sekitar 3.000 ton per tahun (Bappeda, 2013).

Budidaya tanaman kedelai edamame di Kabupaten Jember banyak dikembangkan di beberapa Kecamatan, diantaranya dikembangkan di Kecamatan Ajung dan Kecamatan Jenggawah. Tiap kecamatan memiliki potensi produksi yang berbeda, oleh sebab itu perlu melakukan pengembangan teknologi untuk meningkatkan produksi kedelai, salah satunya dengan melibatkan peran bakteri Rhizobium sp. Bakteri Rhizobium sp. sangat berperan dalam menyuplai unsur hara dari udara dengan bantuan bintil akar.

Pengembangan teknologi untuk meningkatkan produksi kedelai dengan melibatkan bakteri penambat $\mathrm{N}$ dapat dilakukan dengan cara mengisolasi bakteri penambat $\mathrm{N}$ yang berasal dari tanah pada tanaman kedelai edamame di Kabupaten Jember. Isolasi bakteri penambat $\mathrm{N}$ dilakukan untuk mengetahui potensi bakteri Rhizobium sp. pada tanaman kedelai edamame, hal ini dikarenakan pada tiap-tiap lokasi memiliki tingkat adaptasi pertumbuhan bakteri yang berbeda-beda. Hasil isolat bakteri Rhizobium sp. dengan tingkat adaptasi tertinggi yang telah murni dari tanaman kedelai edamame dapat dikembangkan sebagai dasar pembuatan pupuk hayati dan tanaman kedelai dapat bersimbiosis dengan mikroorganisme dalam memenuhi kebutuhan $\mathrm{N}$, sehingga pemenuhan kebutuhan $\mathrm{N}$ tidak hanya bertumpu pada pupuk kimia yang dapat merusak lingkungan dan dapat menghasilkan biji kedelai yang lebih sehat.

Isolasi bakteri penambat $\mathrm{N}$ pada pusat lokasi tanaman kedelai edamame (Glycine $\max$ (L.) Merr.) di Kabupaten Jember bertujuan untuk mengetahui dan mengamati pertumbuhan bakteri penambat $\mathrm{N}$ pada pusat lokasi tanaman kedelai edamame yang ada di Kabupaten Jember dengan menggunakan media YEMA (Yeast Extract Mannitol Agar) serta mendapatkan isolat bakteri Rhizobium sp. murni yang berasal dari pusat lokasi tanaman kedelai edamame di Kabupaten Jember sehingga dapat dipergunakan sebagai dasar pertimbangan dalam perbanyakan bakteri Rhizobium spp. secara massal dan mengurangi penggunaan pupuk anorganik dengan menjadikan Rhizobium spp. sebagai pupuk hayati bagi tanaman kedelai.

\section{METODOLOGI}

Penelitian ini dilakukan dari bulan September 2016 hingga November 2016 di Laboratorium Biosains Politeknik Negeri Jember. Alat yang digunakan dalam pelaksanaan penelitian ini sebagai berikut: tabung reaksi, cawan petri, erlenmeyer, kaca preparat, vortex, gelas ukur, mikroskop, pipet tetes, micro pipet (gilson 
2-20 $\mu 1,20-200 \mu 1,100-1000 \mu \mathrm{l})$, hand sprayer, botol semprot, ependorf tube, gunting, jarum ose, batang L, magnetic stirrer, batang pengaduk, rak tabung reaksi, $\mathrm{pH}$ meter, timbangan analitik, bunsen burner, hot plate stirer, sendok, autoklaf, inkubator, kamera, lemari pendingin, laminar air flow cabinet (LAFC), tip.

Bahan yang digunakan dalam pelaksanaan penelitian ini sebagai berikut: sampel tanah dari pertanaman kedelai edamame, K2HPO4, MgSO4, $\mathrm{NaCl}$, CaCO3, Sukrosa, Yeast Extract, agar, aquadest, Cat Gram (Cristal violet, iodine, alkohol 96\%, Safranin), Brom Thymol Blue (BTB), Congo Red, air, kapas, tissue steril, korek api, kertas label, plastik wrapping, alkohol $70 \%$, plastik.

Sample tanah diambil dari Kecamatan Jenggawah (L1) dan Kecamatan Ajung (L2), masing-masing sebanyak $0,5 \mathrm{~kg}$ pada setiap lokasi dan pada tiga kedalaman tanah, yaitu pada kedalaman $5 \mathrm{~cm}, 10 \mathrm{~cm}$, dan $15 \mathrm{~cm}$ dari permukaan tanah. Pengambilan sampel tanah dilakukan secara random. Pengambilan sampel tanah dilakukan dengan cara mencabut tanaman kedelai edamame yang akan di ambil sampel tanahnya, kemudian di ukur sesuai kedalaman tanah akan di ambil, kemudian melakukan pengambilan sampel tanah pada daerah perakaran tanaman dan dimasukkan kedalam plastik yang telah disediakan.

Pada kegiatan pembuatan Media YEMA (Yeast Extract Mannitol Agar) (K1), bahan-bahan ditimbang menggunakan neraca. Bahan-bahan yang dibutuhkan yaitu $3 \mathrm{~g}$ Yeast Extract, $10 \mathrm{~g}$ Sukrosa, 0,2 g MgSO4 (Magnesium Sulfat), 0,1 g NaCl, 0,5 g K2HPO4, $3 \mathrm{~g}$ $\mathrm{CaCO} 3$, dan $20 \mathrm{~g}$ Agar. Semua bahan yang telah ditimbang kemudian dilarutkan dengan Aquadest sebanyak $1000 \mathrm{ml} \mathrm{di}$ dalam Erlenmeyer dan dilakukan pengecekan $\mathrm{pH}$. $\mathrm{pH}$ yang dibutuhkan dalam pertumbuhan Rhizobium 6,8. Larutan diautoclave selama 15 menit pada suhu $121^{\circ} \mathrm{C}$.

Pembuatan Media YEMA + Congo Red (K2) menggunakan 3 g Yeast Extract, 10 g Sukrosa, 0,2 g MgSO4 (Magnesium Sulfat), 0,1 g NaCl, 0,5 g K2HPO4, $3 \mathrm{~g}$ CaCO3,0,025 g Congo Red, dan $20 \mathrm{~g}$ Agar. Semua bahan yang telah ditimbang kemudian dilarutkan dengan Aquadest sebanyak $1000 \mathrm{ml}$ di dalam Erlenmeyer dan dilakukan pengecekan $\mathrm{pH}$. $\mathrm{pH}$ yang dibutuhkan dalam pertumbuhan Rhizobium 6,8. Larutan diautoclave selama 15 menit pada suhu $121^{\circ} \mathrm{C}$.

Isolasi bakteri dilakukan secara aseptik. Sebelum melakukan isolasi bakteri, perlu dilakukan sterilisasi alat dan bahan menggunakan autoklaf. Sterilisasi dilakukan pada suhu $121^{\circ} \mathrm{C}$.

Isolasi bakteri Rhizobium sp. dilakukan dengan menggunakan metode pengenceran, yaitu dengan cara mengambil sebanyak $1 \mathrm{~g}$ tanah dari masing-masing sampel tanah kemudian dimasukkan kedalam larutan $\mathrm{NaCl}$ 0,85\% sebanyak 9 $\mathrm{ml}$ dalam tabung reaksi, kemudian divortex dan diperoleh seri pengenceran $10^{-1}$. Pengenceran dilanjutkan hingga memperoleh seri pengenceran $10^{-5}$. Suspensi dari seri pengenceran $10^{-5}$ dipipet sebanyak $0,1 \mathrm{ml}$ dan dimasukkan dalam cawan petri yang telah berisi media YEMA, kemudian diratakan dengan spatula, apabila bakteri tidak dapat dihitung maka dilakukan pengenceran berikutnya. Bakteri diinkubasi pada suhu $37{ }^{\circ} \mathrm{C}$ selama selama 5 hari dan diamati setiap 24 jam sekali, kemudian jumlah koloni dihitung dengan metode cawan hitung (plate count).

Bakteri yang telah diisolasi dimurnikan dengan cara mengambil koloni bakteri menggunakan jarum ose, kemudian dimasukkan kedalam aquadest steril sebanyak $5 \mathrm{ml}$ dalam tabung reaksi dan divortex hingga homogen, dilakukan pemipetan sebanyak $0,1 \mathrm{ml}$ dan di 
tumbuhkan ke media YEMA, diratakan dengan spatula, kemudian diinkubasikan pada suhu $37{ }^{\circ} \mathrm{C}$. Koloni yang tumbuh terpisah, dipilih dan ditanam pada media YEMA dalam tabung reaksi sebagai kultur murni.

Gram Staining dilakukan dengan mengambil 1 ose isolat bakteri kemudian digores-goreskan pada permukaan preparat steril sampai rata. Mengambil 1 tetes kristal violet untuk ditambahkan ke preparat yang telah dilapisi bakteri, didiamkan selama 1 menit dan dibilas dengan air hingga zat warna luntur. Kaca preparat dikeringkan di atas api spiritus lalu ditambahkan 1 tetes larutan iod dan didiamkan selama 1 menit, kemudian dilakukan pembilasan dengan air dan didiamkan selama 1 menit hingga preparat kering, selanjutnya membilas dengan alkohol 96\% sampai semua zat warna luntur lalu dicuci dengan air dan dikeringkan di atas api spiritus. Tahap terakhir, safranin ditambahkan sebanyak 1 tetes dan didiamkan selama 45 detik, kemudian dicuci dengan air dan dikeringkan.

Pembuatan Media YEMA + Brom Thymol Blue (K3) menggunakan 3 g Yeast Extract, $10 \mathrm{~g}$ Sukrosa, 0,2 g MgSO4 (Magnesium Sulfat), 0,1 g NaCl, 0,5 g K2HPO4, 3 g CaCO3,0,1 ml BTB 1\%, dan $20 \mathrm{~g}$ Agar. Semua bahan yang telah ditimbang kemudian dilarutkan dengan Aquadest sebanyak $1000 \mathrm{ml}$ di dalam Erlenmeyer kecuali BTB, kemudian dilakukan pengecekan $\mathrm{pH}$. $\mathrm{pH}$ yang dibutuhkan dalam pertumbuhan Rhizobium 6,8. Larutan diautoclave selama 15 menit pada suhu $121{ }^{\circ} \mathrm{C}$, kemudian media dicampurkan dengan BTB dan dituangkan ke dalam cawan petridish.

Karakterisasi isolat dilakukan pada biakan yang sudah murni. Penumbuhan dilakukan dengan cara menumbuhkan bakteri Rhizobium sp. pada media selektif YEMA+Congo Red untuk menguji kemurnian bakteri Rhizobium sp., kemudian diamati perubahan warnanya.

\section{HASIL DAN PEMBAHASAN}

Pengamatan morfologi pada koloni bakteri dilakukan setiap 24 jam sekali selama 5 hari. Pengamatan morfologi dilakukan untuk mengetahui ciri-ciri bakteri secara makroskopis, diantaranya adalah bentuk koloni, bentuk tepian koloni, tekstur koloni, ukuran koloni dari bakteri yang di isolasi, bentuk elevasi bakteri, warna koloni, fase tumbuh bakteri dan bentuk sel bakteri yang diisolasi. Hasil analisis morfologi bakteri penambat $\mathrm{N}$ pada pusat lokasi tanaman kedelai edamame di Kabupaten Jember dapat dilihat pada Tabel 1 di bawah ini:

\begin{tabular}{|c|c|}
\hline Tabel 1. Morfologi & Bakteri \\
\hline Penambat $\mathrm{N}$ & Kecamatan \\
\hline wah dan & Kecamatan Ajung \\
\hline & Morfologi \\
\hline Clr1-cirl Kolonl & Koloni Bakteri \\
\hline Bakterı & Penambat N \\
\hline Bentuk Koloni & Bulat \\
\hline Bentuk Tepian Koloni & \\
\hline Bakteri & Rata atau halus \\
\hline Elevasi Koloni & Cembuno \\
\hline Bakteri & \\
\hline Warna Koloni Bakteri & Putih Susu \\
\hline Awal Pertumbuhan & 24 Jam setelah \\
\hline Koloni Bakteri & Inkubasi \\
\hline Bentuk Sel & Basil \\
\hline Ukuran Bakteri & $1,0-6,0 \mathrm{~mm}$ \\
\hline
\end{tabular}

Hasil analisis morfologi bakteri penambat $\mathrm{N}$ pada pusat lokasi tanaman kedelai edamame di Kabupaten Jember memiliki ciri-ciri bentuk koloni bulat, bentuk tepian bakteri rata, bakteri bentuk elevasinya cembung, memiliki warna putih susu, fase pertumbuhannya dimulai pada saat 24 jam setelah inkubasi dan memiliki bentuk sel basil atau batang. Bentuk sel bakteri Rhizobium sp. batang yang ditunjukkan melalui pengamatan 
mikroskopik pada saat gram staining, ukuran koloni nya sekitar $1,0-6,0 \mathrm{~mm}$, bakteri tersebut merupakan bakteri yang memliki tipe pertumbuhan cepat. Hasil pengamatan morfologi koloni bakteri secara makroskopis menunjukkan bahwa bakteri yang di isolasi merupakan bakteri Rhizobium sp., dimana ciri-ciri bakteri yang diisolasi pada saat pengamatan sama seperti ciri-ciri bakteri Rhzobium $s p$.

Menurut Somasegaran et al., (1985), Irfan, (2014), karakteristik morfologi bakteri Rhizobium sp. pada umumnya memiliki bentuk koloni diskrit, biasanya bentuknya bulat datar, kubah dan bahkan kerucut pada permukaan agar. Koloni yang terbentuk biasanya memiliki tepian yang halus. Warna koloni yang tumbuh biasanya putih susu. Bakteri Rhizobium yang memiliki pertumbuhan cepat pada umumnya dapat tumbuh 3-5 hari setelah di inkubasi, untuk bakteri yang memiliki tipe pertumbuhan lambat akan tumbuh pada 57 hari setelah inkubasi. Ukuran bakteri Rhizobium sp. yang memiliki tipe pertumbuhan lambat memiliki ukuran 1 mm sedangkan bakteri Rhizobium $s p$. yang memiliki tipe pertumbuhan cepat memiliki ukuran 4-5 mm. Pada cawan yang bakterinya padat akan memiliki ukuran yang lebih kecil dan pertumbuhannya menyatu satu sama lain. Ukuran koloni bakteri ditunjukkan pada grafik di bawah ini:

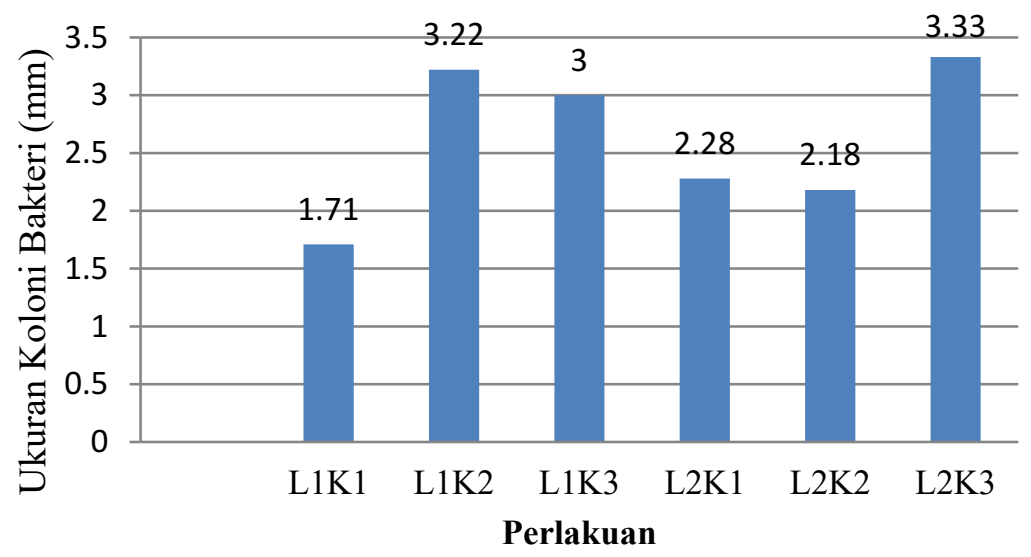

Keterangan:
L1 : Kecamatan Jenggawah
L2 : Kecamatan Ajung
K1 : Media YEMA

K2 : Media YEMA + Congo Red

K3 : Media YEMA + Brom Thymol Blue

Gambar 1. Grafik Ukuran Koloni Bakteri Penambat N

Grafik ukuran koloni bakteri penambat $\mathrm{N}$ menunjukkan bahwa ukuran koloni bakteri terendah berasal dari Kecamatan Jenggawah pada kedalaman 5 $\mathrm{cm}$ dari permukaan tanah, yaitu sebesar $1,71 \mathrm{~mm}$, sedangkan rata-rata ukuran koloni bakteri tertinggi berasal dari kecamatan Ajung pada kedalaman $15 \mathrm{~cm}$ dari permukaan tanah, yaitu sebesar 3,33 $\mathrm{mm}$. Ukuran koloni bakteri berbeda-beda. Bakteri Rhizobium sp. pada umumnya memiliki ukuran koloni antara 1,00-6,00 mm. Bakteri Rhizobium sp. yang memiliki ukuran 1,00 mm pada umumnya merupakan bakteri tipe pertumbuhan slow growing, sedangkan bakteri tipe pertumbuhan fast growing memiliki ukuran antara 3,00-5,00 mm.

Penghitungan jumlah koloni dilakukan dengan cara menghitung jumlah koloni bakteri secara makroskopis dengan alat bantu colony counter. Perhitungan 
jumlah koloni bakteri dilakukan pada tiap sampel isolat bakteri dengan menggunakan rumus kepadatan populasi, kemudian direrata untuk mengetahui jumlah bakteri pada masing-masing perlakuan.

Metode yang digunakan untuk melakukan penghitungan jumlah koloni bakteri adalah metode cawan hitung atau Total Plate Count (TPC), yaitu dengan cara menghitung koloni pada masing-masing cawan petri yang mengandung koloni bakteri sekitar 30-300. Apabila tidak ada, maka dipilih koloni bakteri yang mendekati 300. Penghitungan jumlah koloni dapat dilihat langsung dan kemudian dihitung langsung tanpa alat bantu mikroskop (Irfan, 2014). Hasil analisis terhadap parameter jumlah koloni dapat dilihat pada Tabel 2 di bawah ini:

Tabel 2. Penghitungan Jumlah Koloni bakteri Rhizobium sp.

\begin{tabular}{lc}
\hline Sampel & $\begin{array}{l}\text { Rata-Rata Populasi } \\
\text { Rhizobium sp. / Sampel }\end{array}$ \\
\hline L1K1 & $4,08 \times 10^{24} \mathrm{CFU} / \mathrm{g}$ tanah \\
L1K2 & $4,44 \times 10^{30} \mathrm{CFU/g}$ tanah \\
L1K3 a & $2,52 \times 10^{24} \mathrm{CFU/g} \mathrm{tanah}$ \\
L2K1 & $2,61 \times 10^{30} \mathrm{CFU} / \mathrm{g}$ tanah \\
L2K2 & $2,30 \times 10^{30} \mathrm{CFU} / \mathrm{g}$ tanah \\
L2K3 b & $6,88 \times 10^{30} \mathrm{CFU} / \mathrm{g}$ tanah \\
\hline
\end{tabular}

Keterangan :

a. Populasi bakteri tertinggi berasal dari Kecamatan Ajung pada kedalaman $15 \mathrm{~cm}$ dari permukaan tanah

b. Populasi bakteri terendah berasal dari Kecamatan Jenggawah pada kedalaman $15 \mathrm{~cm}$ dari permukaan tanah

Berdasarkan Tabel 2 hasil penghitungan jumlah koloni dari masingmasing lokasi pengambilan sampel tanah menunjukkan bahwa pada tanah yang berasal dari Kecamatan Jenggawah memiliki populasi bakteri tertinggi yang terdapat pada kedalaman $15 \mathrm{~cm}$ dari permukaan tanah, yaitu sebesar $6,88 \times 10^{30}$ $\mathrm{CFU} / \mathrm{g}$ tanah dan populasi bakteri terendah terdapat pada kedalaman $15 \mathrm{~cm}$ dari permukaan tanah, yaitu sebesar $2,52 \times 10^{24}$
CFU/g tanah. Ditinjau dari kepadatan jumlah bintil akar saat pengambilan sampel tanah, kondisi perakaran yang banyak menghasilkan bintil akar terdapat pada kedalaman $15 \mathrm{~cm}$, sedangkan pada kedalaman tersebut perakaran kedelai edamame tidak menunjukkan adanya bintil akar dalam jumlah banyak, hanya sebagian kecil bintil akar saja yang terdapat pada kedalaman $15 \mathrm{~cm}$ dari permukaan tanah. Jumlah bintil akar yang berbeda sangat mempengaruhi jumlah koloni bakteri pada setiap gram tanah yang di uji. Menurut Saraswati et al., (2007), tanah dengan kandungan $\mathrm{C}$-organik terbesar di alam, yakni $1,2-1,6 \times 10^{15} \mathrm{~kg}$.

Dari hasil pengamatan jumlah koloni bakteri selama 5 hari menunjukkan laju kecepatan pertumbuhan yang berbedabeda. Pada 12 jam setelah masa inkubasi, bakteri yang diisolasi belum menunjukkan adanya pertumbuhan koloni, namun setelah 24 jam bakteri mulai tumbuh. Laju pertumbuhan bakteri tertinggi terdapat pada perlakuan L2K3 yaitu sampel yang berasal dari Kecamatan Ajung pada kedalaman $15 \mathrm{~cm}$ dari permukaan tanah dengan rata-rata jumlah koloni sebesar $5,08 \times 10^{30} \mathrm{CFU} / \mathrm{g}$ tanah, sedangkan laju pertumbuhan koloni bakteri terendah terdapat pada sampel L1K3 yaitu sampel yang berasal dari Kecamatan Jenggawah pada kedalaman $15 \mathrm{~cm}$ dari permukaan tanah dengan rata-rata jumlah koloni bakteri sebsar $1,35 \times 10^{24} \mathrm{CFU} / \mathrm{g}$ tanah. Pada waktu inkubasi 12 jam, bakteri dari seluruh sampel belum mengalami pertumbuhan, hal ini dikarenakan pada masa 12 jam bakteri berada pada fase Lag atau fase dimana bakteri mengalami adaptasi dengan media tumbuh bakteri. Pada masa inkubasi 24 jam bakteri yang diisolasi mulai mengalami pertumbuhan, pada masa tersebut bakteri berada pada fase Log atau fase dimana bakteri mulai tumbuh dan proses pertumbuhannya mulai seimbang. Fase yang ketiga yaitu fase stasioner yang terjadi mulai 48 sampai 96 
jam setelah inkubasi. Pada fase ini bakteri tumbuh secara rutin dan pertumbuhannya stabil serta mengalami peningkatan pertumbuhan. Pada hari ke 4 menuju hari ke 5 atau 120 jam setelah inkubasi, bakteri yang diisolasi tetap tumbuh akan tetapi peningkatan pertumbuhan koloni bakteri mulai berkurang. Bakteri yang diisolasi hanya mengalami perbesaran pertumbuhan atau bahkan tidak mengalami peningkatan penumbuhan, pada fase ini bakteri mulai mengalami penurunan kondisi. Populasi bakteri yang diisolasi selama 5 hari dapat dilihat pada Gambar 2.

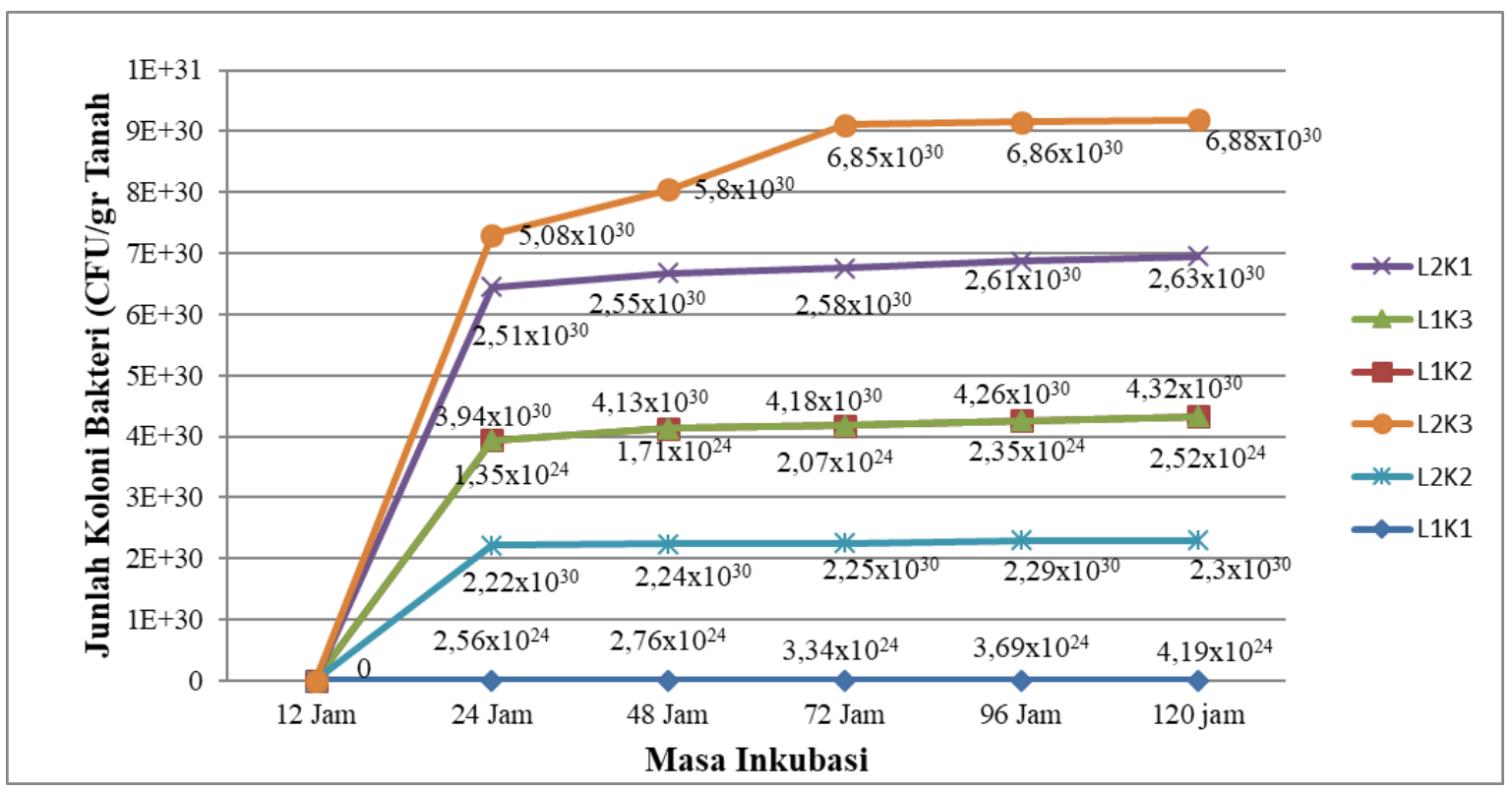

Gambar 2. Grafik Populasi Bakteri selama 5 Hari

Perbandingan sampel tanah yang berasal dari daerah perakaran yang memiliki tanaman dengan sampel tanah tanpa ada tanamannya menunjukkan bahwa tanah yang ditumbuhi tanaman legum akan memiliki jumlah bakteri Rhizobium yang jauh lebih banyak jika dibandingkan dengan sampel tanah tanpa ada tanamanny, hal ini dikarenakan tanaman melakukan aktivitas metabolisme akar yang disebut dengan eksudat yang terdiri dari beberapa senyawa-senyawa gula, asam amino, asam organik, senyawa nucleotide dan basanya, glikosida, enzim, vitamin dan senyawa indole, sehingga dapat digunakan sebagai nutrisi bagi bakteri yang berada didalam tanah sehingga mampu mempertahankan kelangsungan hidupnya (Purwaningsih, 2010).
Perbedaan jumlah koloni yang sangat tinggi tersebut dipengaruhi oleh beberapa faktor, diantaranya adalah faktor sejarah lahan, kondisi fisik lahan, dan umur tanaman kedelai edamame, dan tingkat kedalaman perakaran. Berdasarkan sejarah lahan, baik lahan yang berlokasi di Kecamatan Jenggawah maupun di Kecamatan Ajung merupakan bekas pertanaman kedelai edamame, yang setiap tahunnya selalu digunakan untuk membudidayakan kedelai edamame, sehingga populasi Rhizobium sp. yang ada di pertanaman kedelai edamame semakin meningkat karena tanah terus disuplai dengan bakteri Rhizobium sp.. Keseluruhan populasi bakteri Rhizobium sp. di tanah pada beberapa sampel yang diuji menunjukkan bahwa populasinya termasuk cukup tinggi, hal ini menunjukkan bahwa kondisi tanah di 
Kecamatan Jenggawah dan Kecamatan Ajung termasuk sangat subur.

Tanah pertanian yang subur pada umumnya mengandung lebih dari 100 juta mikroba per gram tanah. Berbagai penambat nitrogen telah banyak diisolasi dari rhizosfer dan rhizoplane tanaman non leguminoceae, namun efisiensi penambatan N2 masih rendah, hal ini disebabkan karena bakteri yang hidup di daerah rhizosfer harus berkompetisi dengan jenis mikroba tanah yang lain untuk mendapatkan eksudat akar demi kelangsungan hidupnya (Kirchhof et al., 1997)

Faktor kondisi fisik lahan sangat mempengaruhi jumlah bakteri yang berkembang di lapang dan tingkat adaptasi bakteri pada media YEMA. Kondisi fisik lahan yang sangat mempengaruhi populasi bakteri di lapang diantaranya adalah tekstur tanah dan $\mathrm{pH}$ tanah. $\mathrm{pH}$ yang diinginkan untuk pertumbuhan dan perkembangan bakteri Rhizobium sp. yaitu sebesar 6,68. Hasil analisa $\mathrm{pH}$ tanah pada kedua lokasi menunjukkan bahwa tanah di Kecamatan Ajung sedikit lebih asam jika dibandingkan dengan $\mathrm{pH}$ tanah di Kecamatan Jenggawah. $\mathrm{pH}$ tanah dari Kecamatan Ajung sebesar 6,63 dan $\mathrm{pH}$ tanah dari Kecamatan Jenggawah sebesar 6,98 . Perbedaan $\mathrm{pH}$ tanah di lapang dengan $\mathrm{pH}$ yang diinginkan untuk pertumbuhan bakteri akan sangat mempengaruhi tingkat pertumbuhan dan daya adaptasi bakteri Rhizobium sp. pH optimal yang mendekati kesesuaian tumbuh bakteri Rhizobium sp. berasal dari Kecamatan Ajung, sehingga populasi bakteri tertinggi berasal dari Kecamatan Ajung. pH tanah dari Kecamatan Ajung cenderung lebih asam jika dibandingkan dengan $\mathrm{pH}$ yang diinginkan oleh pertumbuhan bakteri, akan tetapi bakteri Rhizobium sp. akan dapat berkembang baik pada $\mathrm{pH}$ yang sedikit asam daripada syarat tumbuhnya, dan dapat berkembang baik apabila ditumbuhkan pada media yang memiliki
$\mathrm{pH}$ sesuai dengan kebutuhan tumbuh bakteri.

Analisa tekstur tanah pada sampel yang berasal dari Kecamatan Ajung dan Kecamatan Jenggawah memiliki tekstur geluh lempung debuan, dimana pada saat analisa tekstur tanah secara kualitatif, tanah yang di uji dapat dibentuk seperti pasta dan dapat dibentuk bola serta pita, saat tanah dibentuk pilinan, tidak akan terjadi retakan-retakan dan ketika diletakkan di telapak tangan lalu diberi akuades akan berbentuk menyerupai bubur lalu dirasakan dengan jari telunjuk akan terasa sangat lembut namun licin dan tidak ada tekstur pasiran di dalamnya.

Faktor lain yang juga mempengaruhi perkembangan dan aktivitas rhizobium sp. di dalam tanah antara lain adalah aerasi, jenis tanah dan persentase pasir serta liat, kelembaban, suhu, kandungan bahan organik, kemasaman tanah, dan suplai hara anorganik (Alexander, 1977). Tekstur tanah berpasir yang mengandung bahan organik rendah akan mengurangi populasi bakteri penambatan $\mathrm{N}$ di dalam tanah. Tekstur tanah liat berat dengan bahan organik rendah mengurangi aktivitas dan efektivitas bakteri Rhizobium dalam membentuk bintil akar dan pada akhirnya mempengaruhi penambatan N (Armiadi, 2009).

Pada saat pengambilan sampel perlu mengetahui umur tanaman, melalui pengamatan saat pengambilan sampel di lapang. Tanaman kedelai edamame yang masih pada masa vegetatif tidak mempunyai atau sedikit mempunyai bintil akar, sedangkan sampel yang telah memasuki masa generatif mulai membentuk bintil akar, sehingga dengan adanya bintil akar sampel tanah dapat di ambil dari lapang dan diisolasi, hal ini dikarenakan bintil akar sangat mempengaruhi populasi bakteri Rhizobium sp. Pada umumnya, bintil akar terdapat pada pertanaman kedelai edamame yang mulai berpolong, semakin 
banyak bintil akar maka diharapkan bahwa bakteri Rhizobium yang ada di dalam tanah akan semakin banyak.

Kedalaman perakaran juga sangat mempengaruhi populasi bakteri Rhizobium sp. Semakin subur tanah yang digunakan untuk budidaya kedelai edamame, maka akan semakin dalam perakaran yang menembus tanah, sehingga populasi bakteri Rhizobium sp. akan lebih tinggi. Tanah yang kurang subur akan menyebabkan pertumbuhan bakteri Rhizobium sp. lebih rendah karena proses fiksasi $\mathrm{N}$ tidak berjalan dengan baik.

Hasil analisis gram staining merupakan jenis gram negatif yang menunjukkan warna merah muda pada preparat yang dilihat secara mikroskopik. Bakteri Rhizobium sp. merupakan salah satu jenis bakteri gram negatif yang apabila dilakukan gram staining akan menghasilkan warna merah ataupum merah muda. Pengujian gram staining pada perlakuan lokasi dan kedalaman pengambilan tanah berbeda dan dapat dikatakan positif terdapat bakteri Rhizobium didalamnya.

\begin{tabular}{ccc}
$\begin{array}{c}\text { Tabel 3. Hasil Pengamatan Gram Staining } \\
\text { yang diisolasi dari pusat lokasi } \\
\text { tanaman kedelai edamame di } \\
\text { Kabupaten Jember. }\end{array}$ \\
\hline Perla & Warna hasil & Jenis Gram \\
kuan & Preparat & Bakteri \\
\hline L1K1 & Merah muda & Gram Negatif \\
L1K2 & Merah muda & Gram Negatif \\
L1K3 & Merah muda & Gram Negatif \\
L2K1 & Merah muda & Gram Negatif \\
L2K2 & Merah muda & Gram Negatif \\
L2K3 & Merah muda & Gram Negatif \\
\hline
\end{tabular}

Pewarnaan gram dilakukan untuk mengelompokkan bakteri menjadi 2 jenis, yaitu bakteri gram positif dan bakteri gram negatif. Hasil pewarnaan gram akan sangat dipengaruhi oleh komposisi dinding sel pada bakteri. Proses gram staining ini, terdapat 4 jenis reagen yang digunakan, yaitu kristal violet, iodin, alkohol dan safranin. Bakteri gram negatif memiliki ciri-ciri tidak dapat mempertahankan warna ungu dari kristal violet, akan tetapi dapat menyerap zat warna safranin sehingga akan memperlihatkan warna merah muda sampai merah pada saat di amati menggunakan mikroskop. Bakteri gram positif akan dapat mempertahankan warna ungu dari kristal violet sehingga akan menunjukkan warna ungu ketika diamati dengan mikroskop, selain dapat digunakan untuk melihat jenis gram bakteri, pewarnaan gram juga dapat digunakan untuk mengetahui bentuk morfologi bakteri yang di isolasi (Pratita \& Surya, 2012).

Tabel 4. Tipe Kecepatan Tumbuh Bakteri Rhizobium sp.

\begin{tabular}{lll}
\hline Perlakuan & $\begin{array}{l}\text { Warna } \\
\text { hasil } \\
\text { Preparat }\end{array}$ & $\begin{array}{l}\text { Tipe Kecepatan } \\
\text { Tumbuh }\end{array}$ \\
\hline L1K1 & Kuning & Fast Growing \\
L1K2 & Kuning & Fast Growing \\
L1K3 & Biru & Slow Growing \\
L2K1 & Kuning & Fast Growing \\
L2K2 & Kuning & Fast Growing \\
L2K3 & Kuning & Fast Growing \\
\hline
\end{tabular}

Berdasarkan Tabel 4 dapat diketahui bahwa pengambilan tanah yang berlokasi di Kecamatan Jenggawah dengan kedalaman pengambilan $5 \mathrm{~cm}$ dan $10 \mathrm{~cm}$ dari permukaan tanah merupakan jenis bakteri yang pertumbuhannya cepat atau fast growing, hal ini ditunjukkan dengan perubahan warna kuning yang terjadi selama pertumbuhan, sedangkan isolat bakteri yang berasal dari kedalaman $15 \mathrm{~cm}$ dari permukaan tanah merupakan jenis bakteri dengan pertumbuhan lambat atau slow growing yang ditunjukkan dengan adanya perubahan warna biru pada isolat bakteri. Tipe kecepatan tumbuh bakteri yang berasal dari Kecamatan Ajung dengan kedalaman pengambilan tanah 5 $\mathrm{cm}, 10 \mathrm{~cm}$, dan $15 \mathrm{~cm}$ dari permukaan 
tanah merupakan jenis bakteri yang tipe tumbuhnya cepat, hal ini ditunjukkan dengan perubahan warnanya yang kuning yang terjadi pada 9 sampel yang diamati.

Purwaningsih, (2010) menyatakan bahwa bakteri yang ditumbuhkan dengan menggunakan media seleksi YEMA + Brom Thymol Blue (BTB), memiliki dua kecenderungan warna, yaitu warna kuning dan warna biru. Warna biru menunjukkan bahwa bakteri yang di isolasi pertumbuhannya lambat (slow growing), sedangkan apabila bakteri berubah warnanya menjadi kuning, maka bakteri tersebut merupakan jenis bakteri yang pertumbuhannya cepat (fast growing).

Tabel 5. Kemurnian Bakteri Penambat N

\begin{tabular}{|c|c|c|}
\hline Perlakuan & $\begin{array}{l}\text { Warna hasil } \\
\text { Preparat }\end{array}$ & Jenis Bakteri \\
\hline L1K1 & $\begin{array}{l}\text { Putih - } \\
\text { Merah Muda }\end{array}$ & Rhizobium sp. \\
\hline L1K2 & $\begin{array}{l}\text { Putih - } \\
\text { Merah Muda }\end{array}$ & Rhizobium sp. \\
\hline L1K3 & $\begin{array}{l}\text { Putih - } \\
\text { Merah Muda }\end{array}$ & Rhizobium sp. \\
\hline L2K1 & Merah muda & Rhizobium sp. \\
\hline L2K2 & $\begin{array}{l}\text { Putih - } \\
\text { Merah Muda }\end{array}$ & Rhizobium sp. \\
\hline $\mathrm{L} 2 \mathrm{~K} 3$ & $\begin{array}{l}\text { Putih - } \\
\text { Merah Muda }\end{array}$ & Rhizobium sp. \\
\hline
\end{tabular}

Berdasarkan Tabel 5 dapat diketahui bahwa pengambilan tanah yang berlokasi di Kecamatan Jenggawah dan Kecamatan Ajung merupakan jenis bakteri Rhizobium $s p$. yang menunjukkan warna bakteri putih bening dan merah muda saat ditumbuhkan dengan YEMA+Congo Red yang berarti tidak menyerap atau sedikit menyerap warna merah dari Larutan Congo Red.

Menurut Purwaningsih (2005) salah satu ciri khas bakteri Rhizobium adalah tidak menyerap warna merah pada media yang mengandung Congo Red. Warna yang ditunjukkan dari bakteri Rhizobium $s p$. pada umumnya putih hingga merah muda apabila ditumbuhkan pada media seleksi, bentuk koloni merata datar pada petridish, warna koloni putih susu dengan tekstur yang lengket (Jati, 2014).

\section{KESIMPULAN}

Hasil perhitungan populasi bakteri tertinggi berasal dari Kecamatan Ajung pada kedalaman pengambilan sampel 15 cm dari permukaan tanah, yaitu $6,88 \times 10^{30}$ $\mathrm{CFU} / \mathrm{g}$ tanah. Bakteri yang di isolasi merupakan jenis bakteri gram negatif. Tingkat kemurnian bakteri Rhizobium sp. diketahui dengan menumbuhkan pada media seleksi YEMA+Congo Red yang ditunjukkan dengan perubahan warna putih sampai merah muda.

\section{DAFTAR PUSTAKA}

Alexander, M. (1977). Introduction to Soil 佥 Microbiology (2nd ed.). John Wiley \& Sons.

Armiadi. (2009). Penambatan Nitrogen Secara Biologi pada Tanaman Leguminosa. Wartazoa, 19(1), 2330 .

Badan Penelitian dan Pengembangan 嘻 Pertanian. (2014). Pengembangan Kedelai di Kawasan Lahan Hutan Jati : Upaya Konkret Mendukung Swasembada Kedelai 2014.

Bappeda. (2013). Potensi dan Produk EQ Unggulan Jawa Timur. Retrieved from http://bappeda.jatimprov.go.id/ bappeda/wp-content/uploads/potensi -kab-kota-2013/kota-malang-2013. pdf

Irfan, M. (2014). Isolasi dan Enumerasi

Eakteri Tanah Gambut di Perkebunan Kelapa Sawit PT. Tambang Hijau Kecamatan Tambang Kabupaten Kampar. Jurnal Agroteknologi, 5(1), 1-8. 
Jati, T. N. (2014). Populasi bakteri

尌 penambat nitrogen simbiotik pada rizosfer beberapa vegetasi pionir di lahan bekas erupsi gunung api merapi. Universitas Gajah Mada.

Kirchhof, G., Reis, V. M., Baldani, J. I., 琶 Eckert, B., Döbereiner, J., \& Hartmann, A. (1997). Occurrence, physiological and molecular analysis of endophytic diazotrophic bacteria in gramineous energy plants. In Opportunities for Biological Nitrogen Fixation in Rice and Other Non-Legumes (pp. 45-55). Springer.

Pratita, M. Y. E., \& Surya, R. P. (2012).

Isolasi Dan Identifikasi Bakteri Termofilik Dari Sumber Mata Air Panas Di Songgoriti Setelah Dua Hari Inkubasi. Jurnal Teknik Pomits, $1,1-5$.

Purwaningsih, S. (2005). The isolation, 钢 enumeration, and characterization of Rhizobium bacteria of the soil in Wamena Biological Garden. Biodiversitas Journal of Biological Diversity, 6(2).

Purwaningsih, S. (2010). Populasi Bakteri 镀 Rhizobium di Tanah pada beberapa Tanaman dari Pulau Buton, Kabupaten Muna, Propinsi Sulawesi Tenggara. Jurnal Tanah Tropika (Journal of Tropical Soils), 14(1).

Saraswati, R., Edi, H., \& R.D.M, S. (2007). 期 Metode Analisis Biologi Tanah. (R. Saraswati, E. Husen, \& R. D. M. Simanungkalit, Eds.). Bogor: Balai Besar Penelitian dan Pengembangan Sumberdaya Lahan Pertanian.

Somasegaran, P., \& Hoben, H. J. (1994). 钢 Handbook for Rhizobia. New York, NY: Springer New York. 